\title{
Two cases of monoclonal immunoglobulins with antistreptolysin activity: clinical and laboratory study
}

\author{
F. A. Th. LUSTERMANS AND F. KLEIN \\ From the Department of Internal Medicine I and the Department of Epidemiology, Medical Faculty, \\ Erasmus University, Rotterdam, The Netherlands
}

SUMMARY In two patients with a persisting, high antistreptolysin titre the antistreptolysin activity in both cases resided exclusively in a monoclonal IgG component in the serum. This component had all the characteristics of a true antibody. A history in both patients of arthritis with or without angina suggested that the monoclonal antibodies were reactive in origin, although definite proof was lacking. In one case there was a suggestion of incipient myeloma. Whenever an extremely high antistreptolysin titre persists after antibiotic treatment the possibility of paraproteinaemia should be considered.

Although the monoclonal immunoglobulins are generally assumed not to be true antibodies antibody activity has nevertheless been found in several cases (Potter, 1971). In particular, antistreptolysin-O activity has been found in monoclonal immunoglobulins somewhat surprisingly often. Sauvezie et al. (1974) mention 17 cases of such antibodies out of a total of 57 monoclonal $\mathrm{Ig}$ with antibody activity reported up to 1974 . Other antibody activities comprise rheumatoid factors (Waldenström et al., 1964; Klein et al., 1968), anti-DNA (Riesen and Morell, 1972), antithyroglobulin and antismooth muscle (Wager et al., 1971), antilipoproteins (Beaumont, 1969), and several others. Monoclonal antibodies have also been found or elicited in animals (Osterland et al., 1966; Potter, 1971; van den Berg et al., 1976).

In most instances the activity of such antibodies, which may belong to any Ig class, has no demonstrable connection with the disease in which they are occurring or with any previous illness. In some cases, however, such a connection has been suggestedfor example, by Sauvezie et al. (1974) and by Seligmann et al. (1968, 1973). Most of the monoclonal antibodies appear in cases of multiple myeloma or Waldenström's macroglobulinaemia or in the less well-defined group of 'benign' monoclonal gammapathies (Waldenström, 1964). Monoclonal antibodies against human erythrocyte components (cold agglutinins) appear either without known

Received for publication 4 April 1977 aetiology (Harboe and Torsvik, 1969) or, in some cases, after an infection with Mycoplasma pneumoniae (Feizi and Schumacher, 1968). The reactions of some monoclonal IgGs with staphylococcal protein A were shown by Kronvall (1967) to be localised in the Fc part of the IgG molecule and are therefore considered to be aspecific. Binding of the supposed antigen with $F(a b)$ or $F\left(a b^{\prime}\right)_{2}$ should therefore always be demonstrated.

We describe two cases of monoclonal IgG with antistreptolysin activity that suggest a causal relationship with a previous disease, although a definite proof is lacking.

\section{Methods}

\section{SERUM PROTEIN ANALYSIS}

Electrophoresis of the serum was performed on cellulose acetate (Cellogel) strips in a twofold dilution to obtain linearity in scanning. Densitometry of the electropherogram was carried out with the Joyce Loebl Chromoscan MK II densitometer. The results were recorded as percentages of total protein as obtained with a biuret method. Immunoelectrophoresis with specific anti light- and heavy-chain sera was used to identify the paraproteins. The protein content of the IgG paraprotein fractions was obtained from the densitogram, since the radial immunodiffusion method may not be valid for monoclonal immunoglobulins.

Preparative electrophoresis was performed on a starch block according to Bloemendal (1960) 
The $\gamma$-region was divided into portions which were eluted, concentrated, and analysed separately.

PREPARATION OF $F\left(\mathrm{ab}^{\prime}\right)_{2}$ FRAGMENTS

IgG was isolated from the patients' serum by chromatography over DEAE cellulose (Cellex, Calbiochem) by the method of Levy and Sober (1960) with slight modifications. The IgG preparations containing the paraprotein as well as heterogeneous IgG were then digested with pepsin according to Nisonoff and Mandy (1962) with minor modifications. A similar amount of a preparation of normal IgG obtained from the Dutch Red Cross Laboratory (Amsterdam) was digested under identical conditions and served as a control in the antistreptolysin test. $F\left(a b^{\prime}\right)_{2}$ fragments were isolated from the digest by gel filtration through Sephadex G-100.

Antistreptolysin titres were determined according to Rantz and Randall (1945). Aspecific reactions in the antistreptolysin test due to $\beta$-lipoprotein were excluded by precipitation according to Cabau and Badin (1966). Anti-DNAse B titres were measured as described by Klein et al. (1969).

\section{Case reports}

CASE 1

A 61-year-old woman had suffered from vague complaints of pain since early January 1966. The pain started retrosternally, radiated to the epigastrium, was continuous, and worsened gradually with accompanying attacks of motion restlessness. Fourteen days after the symptoms began she ran a fever and a migratory arthritis of the large joints. The joints were warm, swollen, and so painful that she was unable to tolerate blankets on her legs. She noticed nodules on her legs, which persisted for a few days. There had been no preceding pharyngitis. She had always been in good health except for a recurrent episcleritis in the last seven years, which was treated with cortisone eyedrips. Her general practitioner treated her present complaints with two injections of long-acting penicillin intramuscularly and sent her for admission.

In the hospital we saw an ill-looking woman with a temperature of $39.6^{\circ} \mathrm{C}$; pulse rate $80 / \mathrm{min}$, regular; and blood pressure $130 / 80 \mathrm{~mm} \mathrm{Hg}$. The tonsils were small and not inflamed. Auscultation of the heart and lungs was normal. The abdomen was soft and peristalsis was normal. The liver and spleen were not palpable. The joints were painful, with all the characteristics of inflammation. The ESR was $134 \mathrm{~mm}$ in $1 \mathrm{~h}$, haemoglobin $6.8 \mathrm{~g} / \mathrm{dl}$, packed cell volume $34 \%$, leucocytes $10.5 \times 10^{9} / 1\left(10500 / \mathrm{mm}^{3}\right)$ with a normal differential count. The serum creatinin, uric acid, liver function tests, and cholesterol were all normal. The serum total protein was $72.5 \mathrm{~g} / 1$ with an albumin:globulin ratio of $0 \cdot 69$. The albumin was $27.6 \mathrm{~g} / \mathrm{l}$, alpha-1 globulin $4.9 \mathrm{~g} / \mathrm{l}$, alpha-2 globulin $9.2 \mathrm{~g} / \mathrm{l}$, beta-globulin $13.6 \mathrm{~g} / \mathrm{l}$, gammaglobulin $15 \cdot 7 \mathrm{~g} / 1$. On paper electrophoresis there was an abnormal peak in the slow gammaglobulin fraction. Tests for Bence Jones proteins were repeatedly negative. Each of six blood cultures was negative. Throat culture yielded a haemolytic streptococcus which did not belong to Lancefield's group A but was not further determined. The antistreptolysin-O titre was 62500 units $/ \mathrm{ml}$. The Rose test, antinuclear factor test, and $\mathrm{C}$-reactive protein reaction were all negative.

Bone-marrow smears showed a plasma cell reaction with a few atypical plasma cells. $X$-ray investigations of the chest, stomach, gall bladder, kidneys, spine, and bones were all normal. The ECG showed a sinus rhythm without any abnormality.

In terms of diagnosis the patient had (1) acute rheumatic fever according to the Jones criteria (migratory polyarthritis, subcutaneous nodules, fever, high ESR, leucocytosis, and raised AST); (2) plasma cell reaction with a few atypical plasma cells and paraproteinaemia; (3) episcleritis.

During two weeks of bed rest without other therapy $\varnothing$ the patient's fever, abdominal pain, and joint complaints subsided and the ESR fell to $94 \mathrm{~mm}$ in $1 \mathrm{~h}$.0ิ Later she was put on a 10-day course of penicillin $\mathrm{G}$ followed by long-acting penicillin $\left(1.2 \times 10^{6}\right.$ units benzathine-penicillin every 14 days). Since that time she has been followed up as an outpatient. In October 1966. July 1968, and February 1975 she again suffered from arthritis with fever. Tonsillectomy was performed in 1967 without any effect on the high ASO-titre. Therefore the penicillin therapy was stopped in December 1967. Her ASO-titre always remained very high. showing unexplained fluctuations. Her last bone-marrow smear in February 1974 was entirely normal. Until the end of 1976 the amount of monoclonal IgG showed only insignificant fluctuations.

\section{CASE 2}

A 47-year-old woman underwent tonsillectomy in 1961 because of repeated complaints of angina with arthralgia. In 1972 she suffered a few attacks of sore throat with malaise and joint complaints but without fever. The dorsum of the left hand, forefinger, and both ankles were painful and swollen during the attacks. Her general practitioner, on repeated examinations, found only swollen joints and no enlarged lymph nodes or other abnormalities. As the ESR was $26 \mathrm{~mm}$ in 1 hour and the ASO-titre $>16000$ units $/ \mathrm{ml}$ she was treated with penicillin $\mathrm{G}$ followed by a monthly prophylactic $\left(1.2 \times 10^{6}\right.$ units 
of benzathine-penicillin intramuscularly). Shortly afterwards she developed discomfort in the hypochondrium which lasted a month and disappeared spontaneously. Because of a high and fluctuating ASO-titre (from > 6400 to $>32000$ units $/ \mathrm{ml}$ ) she was referred to the outpatient department in March 1973.

Physical examination yielded no abnormalities. The joints were clinically normal. Laboratory examination showed an increased ESR of $26 \mathrm{~mm}$ in $1 \mathrm{~h}$, haemoglobin $8.8 \mathrm{~g} / \mathrm{dl}$, packed cell volume $43 \%$, and leucocytes $7.5 \times 10^{9} / 1\left(7500 / \mathrm{mm}^{3}\right)$. The serum creatinin, uric acid, and liver function tests were all normal. The plasma cholesterol concentration was $9 \mathrm{mmol} / \mathrm{l}(390 \mathrm{mg} / 100 \mathrm{ml})$ (upper limit of normal value $7.5 \mathrm{mmol} / 1(300 \mathrm{mg}$ / $100 \mathrm{ml})$ ). The Rose test and anti-nuclear factor test were negative and the ASO-titre was 153600 units $/ \mathrm{ml}$. The bone-marrow smear showed $7 \cdot 8 \%$ plasma cells. The total serum protein was $76.6 \mathrm{~g} / \mathrm{l}$. Paper electrophoresis showed albumin $47 \cdot 7 \mathrm{~g} / \mathrm{l}$, alpha-1 globulin $2 \cdot 2 \mathrm{~g} / 1$, alpha-2 globulin $5 \cdot 5 \mathrm{~g} / \mathrm{l}$, betaglobulin $5.5 \mathrm{~g} / \mathrm{l}$, and gammaglobulin $15.5 \mathrm{~g} / \mathrm{l}$ with an abnormal peak in the gammaglobulin area.

The diagnosis, based on plasma cell reaction with paraproteinaemia, was suggestive of myeloma. The penicillin therapy was discontinued and a continuing watch was kept on the amount of paraprotein in the serum. In July 1976 the patient had a recurrence of sore throat with joint complaints, which disappeared spontaneously. No new abnormalities were found on laboratory examination. Up to the end of 1976 there had been no increase in the production of monoclonal IgG.

\section{Results of immunochemical investigations}

\section{CASE 1}

In the electropherogram of the patient's serum a paraprotein band was found in the slow $\gamma$ region. Immunoelectrophoresis showed that it was an IgG paraprotein (Fig. 1). This was confirmed by testing block electrophoresis fractions containing the paraprotein with mono-specific antisera. Analysis of the same fractions by double diffusion against specific anti- $\kappa$ and anti- $\lambda$ serum showed that the IgG paraprotein was of $\kappa$-light chain type (Fig. 2).

In preparative electrophoresis the paraprotein appeared in two adjoining fractions, the heterogeneous immunoglobulin in at least three others (Fig. 2). Testing of these fractions for antistreptolysin activity yielded the results indicated in Fig. 2. Almost all the antistreptolysin activity is restricted to the paraprotein fractions 1 and 2 , all the others having negligible activity. These results were confirmed in another experiment.

To prove that this activity is a true antibody

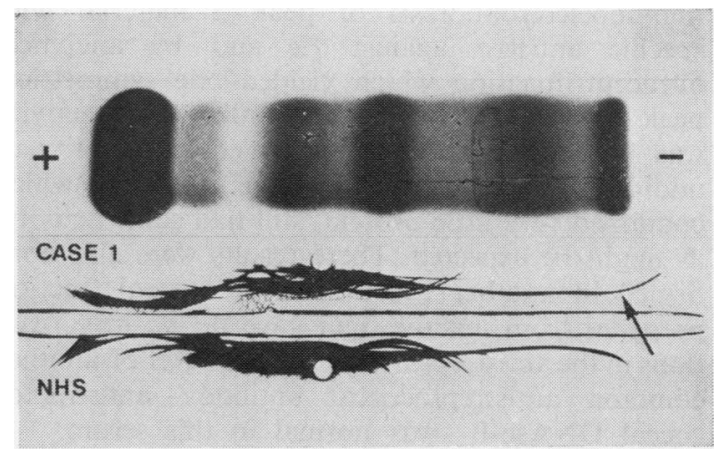

Fig. 1 Electrophoresis and immunoelectrophoresis of the serum of case 1. Arrow indicates monoclonal IgG.

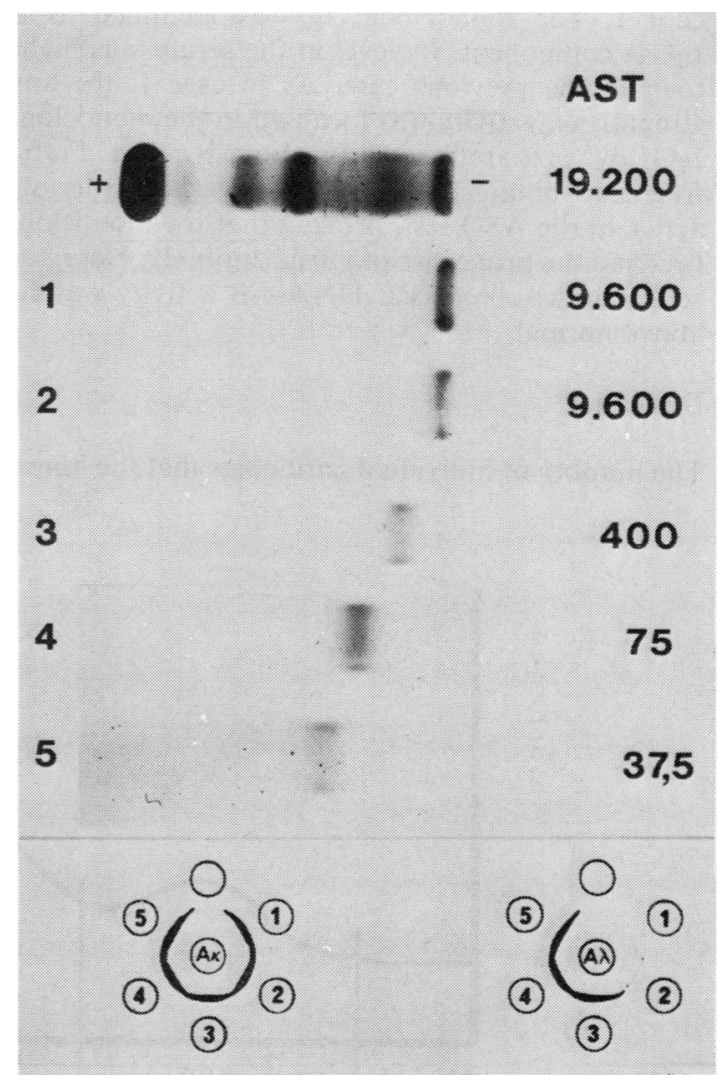

Fig. 2 Analysis of electrophoretic fractions of serum of case 1. Above-localisation of the monoclonal component and the ASO-titre in starch block fractions 1-5. Belowlight chain typing in the same fractions. 
activity it is necessary to show that it is located in the $F\left(a b^{\prime}\right)_{2}$ fragment. Figure 3 shows the G-100 elution diagram. Peak 1 represents undigested IgG, peak 2 the $F\left(a b^{\prime}\right)_{2}$ fragments. This was confirmed by immunoelectrophoresis of peak 2 material with specific antisera against $\mathrm{Fc}$ and by analytical ultracentrifugation which yielded one symmetrical peak with $S_{20}=4.9 \mathrm{~S}$. The bulk of the activity was in peak 2 , the titre of an equal quantity of undigested IgG being the same. Peak 1, which contained very little protein, still had some activity, as might be expected. These results were also confirmed in another experiment. A control fraction prepared from inactive IgG gave no positive reactions in the antistreptolysin test. The level of another common antistreptococcal antibody-antistreptococcal DNAse-B-was normal in this serum.

\section{CASE 2}

This patient had a paraprotein band in the serum in the slow $\gamma$ region, somewhat less cathodic than in case 1 . The monoclonal Ig was identified as an IgG- $\lambda$ component. Its level in the serum was higher than in the previous case. As in case 1, the antistreptolysin activity was localised in the monoclonal IgG by preparative electrophoresis. The $F\left(a b^{\prime}\right)_{2}$ fragment obtained by pepsin digestion was still active in the ASO test, proving that the monoclonal IgG had the properties of a true antibody. Here, too, serum antistreptococcal DNAse-B activity was not above normal.

\section{Discussion}

The number of individual antibodies that the human body is able to produce, and therefore the number of all clones making these antibodies, is estimated to be in the order of $10^{6}$ (Wager et al., 1971). If the $\overrightarrow{\vec{F}}$ development of such a clone towards autonomousproduction and perhaps ultimate malignancy is a $\frac{\square}{0}$ chance event the probability of detecting a mono- $\frac{\bar{\sigma}}{\bar{c}}$. clonal antibody at all would be very small. The $\vec{\varnothing}$ relative frequency with which, in particular, mono- $\frac{2}{0}$ clonal antistreptolysins have been discovered would ${ }^{\text {क }}$ seem to be in contradiction to this supposition. $\overrightarrow{0}$ Therefore it is important to search for exogenous $\vec{\longrightarrow}$ stimuli favouring the production of certain mono- $\bar{\omega}$ clonal antibodies. If such stimuli could be found we would have to suppose that they could, under as yet unknown circumstances, lead to an autonomous production of antibody and eventually to malignancy.

The myeloma patient with a previous history of $\vec{\circ}$ rheumatic fever and a similar patient with an anti- $\vec{C}$ body against horse $\alpha_{2}$-macroglobulin and a previous $\vec{c}$ history of immunisation with horse serum, both $\mathbb{D}$ described by Seligmann et al. $(1968,1973)$, would $\underset{\mathbb{D}}{\mathbb{P}}$ seem to represent such cases. Other cases, such as $\bar{\sigma}$ those described by Sauvezie et al. (1974) and Wager $\stackrel{\mathbb{Q}}{-}$ et al. (1971), also point in this direction. The anti- $\vec{\bullet}$ bodies with restricted heterogeneity, such as those found by Yount et al. (1968) in humans and Roholt et al. (1970) in immunised rabbits, might an intermediate stage. In rabbits the tendency to form antibodies with restricted heterogeneity is supposed to be genetically determined (Eichmann et al., 1971).

Both cases described here would seem to suggest a 'reactive' origin of the monoclonal antibodies, since both patients had a history reminiscent of rheumatic

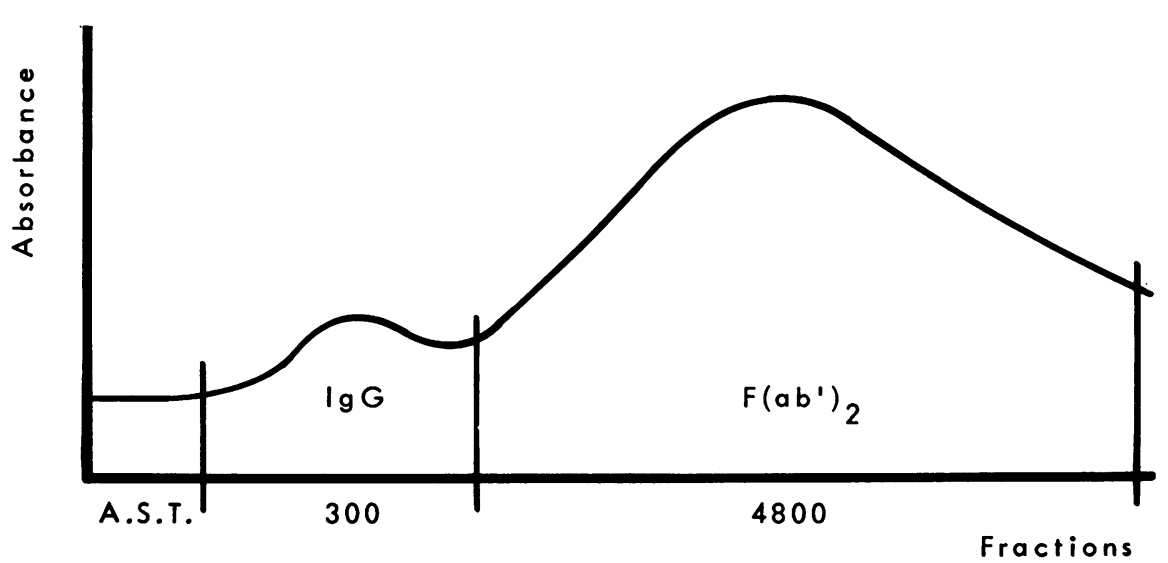

Fig. 3 Fractionation of serum of case 1 through a G-100 column. Composition and ASO-titre of the two peaks is indicated in the diagram. 
fever. In the first case, however, the monoclonal fraction was observed only a few weeks after the onset of the first symptoms. This seems to be a very short period for such a development, since there seemed to be no previous history of rheumatic fever. In the second case a stimulus for the monoclonal antibody might have been present, but no electrophoretic pictures of the initial phase or before were made. The final evidence for the reactive origin of the monoclonal components was difficult if not impossible to obtain in both cases.

It would be of importance to study the past history of cases with a monoclonal antibody against streptolysin. Equally important are the prospects of such cases. Waldenström (1964) has observed that monoclonal gammapathies may remain in a benign state for many years, although Nørgaard (1971) has found a development towards malignancy after as many as 24 years in some cases. Follow-up of the quantity of monoclonal protein by electrophoretic scanning is therefore important.

Clinically speaking a search for a monoclonal antibody should be undertaken as soon as an unusually high ASO-titre persists after antibiotic treatment. Serum electrophoresis in such a case is at least as important as a further search for causative bacteria. If a monoclonal antibody is found bone marrow cytology should give an impression of possible malignancy.

Careful clinical and laboratory study, prospective as well as retrospective, should ultimately throw more light on the intriguing phenomenon of monoclonal antibody development.

The antistreptolysin titres were measured under the supervision of Dr J. C. Lorrier. The technical assistance of Mrs M. Hagenaar-de Weerdt and Mr R Vermeeren with the biochemical work is gratefully acknowledged. We also thank Professor H. A. Valkenburg for helpful suggestions.

\section{References}

Beaumont, J. L. (1969). Gamma-globulines et hyperlipidémies e'hyperlipidémie par auto-anticorps. Annales de Biologie Clinique, 27, 611-635.

van den Berg, P., Radl, J., Löwenberg, B., and Swart, A. C. W. (1976). Homogeneous antibodies in lethally irradiated and autologous bone marrow reconstituted Rhesus monkeys. Clinical and Experimental Immuno$\log y, 23,355-359$.

Bloemendal, H. (1960). Starch electrophoresis, I. Starch block electrophoresis. Chromatographic Reviews, 2, 44-58.

Cabau, N., and Badin, J. (1966). Étude de l'inhibition non spécifique de la streprolysine $O$. Nouvelles méthodes de dosage du pouvoir inhibiteur de la
B-lipoprotéine. Revue Français d'études Cliniques et Biologiques, 11, 533-536.

Eichmann, K., Braun, D. G., and Krause, R. M. (1971). Influence of genetic factors on the magnitude and the heterogeneity of the immune response in the rabbit. Journal of Experimental Medicine, 134, 48-65.

Feizi, T., and Schumacher, M. (1968). Light chain homogeneity of post-infective cold agglutinins. Clinical and Experimental Immunology, 3, 923-929.

Harboe, M., and Torsvik, H. (1969). Protein abnormalities in the cold haemagglutinin syndrome. Scandinavian Journal of Haematology, 6, 416-426.

Klein, F., van Rood, J. J., van Furth, R., and Radema, H. (1968). IgM-IgC cryoglobulinaemia with IgM paraprotein component. Clinical and Experimental Immuno$\log y$, 3, 703-716.

Klein, G. C., Baker, C. N., Addison, B. V., and Moody, M. D. (1969). Microtest for streptococcal antideoxyribonuclease B. Applied Microbiology, 18, 204-206.

Kronvall, G. (1967). Ligand-binding sites for streptolysin $O$ and staphylococcal protein $A$ on different parts of the same myeloma globulin. Acta Pathologica et Microbiologica Scandinavica, 69, 619-621.

Levy, H. B., and Sober, H. A. (1960). A simple chromatographic method for preparation of gamma globulin. Proceedings of the Society for Experimental Biology and Medicine, 103, 250-252.

Nisonoff, A., and Mandy, W. J. (1962). Quantitative estimation of the hybridization of rabbit antibodies. Nature, 194, 355-359.

Nørgaard, O. (1971). Three cases of multiple myeloma in which the preclinical asymptomatic phases persisted throughout 15 to 24 years. British Journal of Cancer, 20, 417-422.

Osterland, C. K., Miller, E. J., Karakawa, W. W., and Krause, R. M. (1966). Characteristics of streptococcal group-specific antibody isolated from hyperimmune rabbits. Journal of Experimental Medicine, 123, 599-614.

Potter, M (1971). Myeloma proteins (M-components) with antibody-like activity. New England Journal of Medicine, 284, 831-838.

Rantz, L. A., and Randall, E. A. (1945). A modification of the technic for determination of the anti-streptolysin titer. Proceedings of the Society for Experimental Biology and Medicine, 59, 22-25.

Riesen, W., and Morell, A. (1972). A human myeloma protein with specificity against dinitrophenyl and nucleic acid derivatives. Immunochemistry, 9, 979-985.

Roholt, O. A., Seon, B. K., and Pressman, D. (1970). Antibodies of limited heterogeneity; L chains of a single mobility. Immunochemistry, 7, 329-340.

Sauvezie, B., Missioux, D., Leroy, V., Wahl, D., Goumy, P., Bussière, J. L., and Rampon, S. (1974). Une nouvelle observation de myélome dont la paraprotéine possède l'activité anti-streptolysine O. Revue du Rhumatisme et des Maladies Ostéo-Articulaires, 41, 449-453.

Seligmann, M., Danon, F., Basch, A., and Bernard, J. (1968). IgG myeloma cryoglobulin with antistreptolysin activity. Nature, 220, 711-712. 
Seligmann, M., Sassy, C., and Chevalier, A. (1973). A human IgC myeloma protein with anti- $\alpha_{2}$ macroglobulin antibody activity. Journal of Immunology, 110, 85-90.

Wager, O., Räsänen, J. A., Haltia, K., and Wasastjerna, C. (1971). M-components with antibody activity: anti-smooth muscle, anti-thyroglobulin and antistreptolysin-O activity in five $\mathbf{M}$ component sera. Annals of Clinical Research, 3, 86-97.

Waldenström, J. (1964). The occurrence of benign, essential monoclonal (M-type), non macro-molecular hypergammaglobulinemia and its differential diagnosis IV. Studies in the gammapathies. Acta Medica Scandi- navica, 176, 345-365.

Waldenström, J., Winblad, S., Hällén, J., and Liungman S. (1964). The occurrence of serological 'antibody reagins or similar $\gamma$-globulins in conditions with monoclonal hypergammaglobulinemia, such as myeloma, macroglobulinemia, etc. Acta Medica Scandi $\frac{\bar{D}}{\bar{D}}$ navica, 176, 619-631.

Yount, W. J., Dorner, M. M., Kunkel, H. G., and Kabat $\stackrel{\mathbb{\Omega}}{\Omega}$ E. A. (1968). Studies on human antibodies. VI Selective variations in subgroup composition and ${ }^{\text {s }}$ genetic markers. Journal of Experimental Medicine, $\overrightarrow{0}$ 127, 633-646.

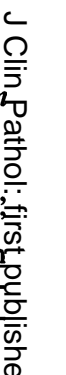

